\title{
Enhanced Abrasion Resistance of Coated Particleboard Pre-Treated with Atmospheric Plasma
}

\section{Pojačana otpornost na abraziju premazanih iverica prethodno obrađenih atmosferskom plazmom}

Original scientific paper • Izvorni znanstveni rad Received-prispjelo: 20. 10. 2019.

Accepted-prihvaćeno: 28. 4. 2020.

UDK: $630 * 812.733 ; 630 * 863.21$

https://doi.org/10.5552/drvind.2020.1960

(C) 2020 by the author(s). Licensee Faculty of Forestry, University of Zagreb. This article is an open access article distributed under the terms and conditions of the

Creative Commons Attribution (CC BY 4.0) license.

\begin{abstract}
This study aims to investigate the influence of atmospheric plasma treatment on the abrasion resistance of particleboards, as an example of a wood-based material, coated with a waterborne finish. The treatment of the substrate, prior to coating application, using a floating-electrode dielectric barrier discharge (FE-DBD) plasma, resulted in an enhanced abrasion resistance of the coated particleboards in comparison to the untreated ones during the abrasion test with a duration of 200 revolutions. This finding was related to lower contact angles of water and coating after treatment with plasma and greater hardness of the coating on the treated substrates. The micrographs of the sample cross sections recorded with scanning electron microscope showed differences in the amounts of remained coating on the abraded areas. Investigation with attenuated total reflection Fourier transform infrared spectroscopy revealed that treatment of the substrate with plasma did not affect the chemical composition nor the curing and structure of the later applied coating. Further studies should be performed to determine the resistance properties of such surface systems to other impacts.
\end{abstract}

Keywords: particleboard; plasma; coating; abrasion

SAŽETAK • Cilj ovog rada bio je istražiti utjecaj atmosferske plazme na otpornost iverica na abraziju, kao primjer materijala na bazi drva premazanoga vodenim premazom. Tijekom ispitivanja abrazije u trajanju od 200 ciklusa obrada iverica uz pomoć plazme (FE-DBD) prije nanošenja premaza rezultirala je poboljšanom otpornošću premazanih iverica na abraziju u usporedbi s neobrađenom ivericom. Rezultat istraživanja povezan je s nižim kontaktnim kutom vode i premaznog materijala nakon obrade iverica plazmom is većom tvrdoćom premaza na podlozi obrađenoj plazmom. Mikrografije presjeka uzorka dobivene pretražnim elektronskim mikroskopom pokazale su razlike u količini preostalog premaza na površinama ispitanima na otpornost na habanje. Ispitivanje infracrvenom spektroskopijom uz prigušenu totalnu refleksiju pokazalo je da obrada podloge plazmom nije utjecala na kemijski sastav ni na otvrdnjavanje i strukturu kasnije nanesenog premaza. Potrebno je provesti daljnja ispitivanja kako bi se dodatno utvrdila otpornost takvih površinskih sustava.

Ključne riječi: iverica; plazma; premaz; abrazija

\footnotetext{
${ }^{1}$ Authors are $\mathrm{PhD}$ candidate, assistant professor, professor and teaching assistant at University of Ljubljana, Biotechnical Faculty, Department of Wood Science and Technology, Ljubljana, Slovenia.
} 


\section{INTRODUCTION}

\section{UVOD}

Surfaces of wood and wood-based products in interior and exterior applications are exposed to a number of physical and mechanical stresses. Protection or resistance of the wooden structure against physical and chemical influences can be obtained by surface treatment, which depends on selected coating and the type of substrate (Keskin and Tekin, 2011; Veigel et al., 2014). Protection and durability of the material are important with regard to economy and manufacturing technique. Chemical and anatomical structure of wood, as well as its properties such as density, surface roughness and colour, may affect the effect of the coating. In indoor applications, the mechanical coating properties are of a prime importance, especially those like surface hardness, deformability as well as resistance to impact, friction, scratch and abrasion (Brischke et al., 2019). Mechanical properties of a coating strongly depend on the binder type and the film thickness (Keskin and Tekin, 2011). Nowadays, different nanoparticles are added to the coating formulations to enhance their resistance to physical, chemical and mechanical impacts (Cristea et al., 2011).

Particleboard is a wood-based panel consisting of wood or other lignocellulosic particles of various sizes, manufactured by bonding them together with a synthetic resin or binder under heat and pressure. Particleboard is used widely in the manufacture of domestic, institutional and office furniture, stair treads, cabinetry, counter tops, speakers, core for doors, signs, displays, shelving, table tops, subflooring in constructions and other industrial product application due to the smooth surface, uniform density and thickness, dimensional stability, strength, machining ability, and screw-holding capacity (Bardak et al., 2011). Usually, the boards have to be overlaid (by veneers, laminates, impregnated papers, foils) or coated (application of liquid finishing materials with various finishing techniques) to meet the specific requirements of their final use. In the case of painted or overlaid boards, irregularities in the substrate, or the differences in thickness of the coating film, may have a negative impact on the adhesion of paints and overlays and hence on the quality of the final product. Uniform and flat panels provide an excellent surface for the application of coating materials, like paint, print, or varnish substances. Together forming a surface system, the performance of the coated panels is dependent on the quality of wood based panel, the type of the coating material, and a good compatibility between both (Nemli et al., 2005; Rolleri and Roffael, 2010; Bardak et al., 2011). As an example of the latter, a rough surface gives paints several possibilities to penetrate and create strong joins, but on the other hand, by very high roughness, an excessive volume of paint necessary to give surfaces a smooth appearance is expected (Rolleri and Roffael, 2010). Nowadays, waterborne coatings are increasingly used due to the reduced impact on the user and environment. Besides the appearance, one of the requirements of coatings for interior flooring is the ability to withstand mechanical loads like wear, erosion and abrasion (Scrinzi et al., 2011; Sell and Feist, 1986).

Various methods upgrade the appearance and features of coated wooden materials, extending their lifetime and increasing their value (Nemli and Hiziroglu, 2009). Improved scratch and abrasion resistance can be induced by the use of additives such as inorganic fillers and nanoparticles $\left(\mathrm{SiO}_{2}, \mathrm{Al}_{2} \mathrm{O}_{3}\right.$, carbonates, silicates and sulfates of various metals) with high hardness (Bauer et al., 2006; Veigel et al., 2014). Furthermore, the abrasion resistance depends on the adhesive used for the panel production (Bardak et al., 2011).

In applications of coatings for interior, besides proper protection properties and a suitable appearance, good resistance to impact and abrasion are expected (Rossi et al., 2009; Keskin and Tekin, 2011). Concerning load bearing applications, the resistance of the material used to abrasion becomes the decisive mechanical property (Welzbacher et al., 2009). Surface quality of wood composites such as particleboard is an important physical property influencing different processes, including their finishing (Istek et al., 2010). There are various methods and devices to simulate the abrasion conditions of the components, and finally measure and determine the resistance of wooden materials to abrasion according to weight loss or wear through the coating after a defined time of wearing. The most useable method for the determination of abrasion resistance of various surface systems is the Taber Abraser test (Rossi et al., 2005; Bauer et al., 2006; Rossi et al., 2009; Aytin et al., 2015).

Electrical gas discharges, more commonly known as plasmas (Žigon et al., 2018; Altgen et al., 2019), can be used to enhance the interaction of wood and woodbased materials surfaces with applied coatings and other liquids. These plasmas can be generated in air at atmospheric pressure, presenting a cost efficient and clean technology. The effects caused by such a treatment of the substrate, via physical and chemical reactions, contribute to enhanced wettability, penetration, adhesion of the applied polymer and final properties of the formed surface system (Liston et al., 1993; Wolkenhauer et al., 2008; Wolkenhauer et al., 2009; Wolf and Sparavigna, 2010; Altgen et al., 2015; De Cademartori et al., 2016; Perisse et al., 2017; Reinprecht et al., 2018). Generally, the basic concept for increasing the surface free energy by plasma treatment (PT) is either breaking polar bonds and leaving polar end groups, or adding polar groups to the surface (Ko et al., 2018). A combination of mechanical abrasion followed by PT enhances the bonding quality (Moghadamzadeh et al., 2011), but this is highly dependent on the type of plasma reactor and treatment conditions. By some plasma pre-treatments, the microstructure of treated wooden material can be altered. Coating penetration increases after exposure of the substrate to plasma. The solventborne as well as waterborne polyurethane coating showed deeper penetration on PT wood than on the untreated one. The ability of PT to improve coating performance on wood depends on the coating type and the 
effects of the treatment on the surface microstructure of wood (Haase et al., 2019).

Pendulum hardness test is one of the most widely used methods for determining the coating hardness. The measured value of hardness greatly depends on the thickness of the coating; it gradually decreases with the increasing coating thickness (Sönmez et al., 2011; Ma et al., 2013; Gurleyen et al., 2017).

Based on the cited literature and our previous research work, the aim of the present study was to investigate whether the treatment of wood-based materials surfaces with atmospheric plasma influences the abrasion resistance of a coating. For this purpose, a particleboard substrate with homogenous structure and a waterborne coating were selected as research materials. The treatment of the substrate with plasma, prior to coating application, was performed using a floatingelectrode dielectric barrier discharge device (FE-DBD, Žigon et al., 2019). We hypothesize that PT that increases adhesion and penetration depth of waterborne coating into wood-based materials, further leads to improved resistance of surface system to abrasion. Detailed interactions between untreated or PT substrate and coating were investigated by the measurement of water and coating droplets contact angle (CA). Besides the determination of abrasion resistance, measurements of coated surface hardness were performed, while the appearance of coated samples cross sections was studied with scanning electron microscope. In order to detect possible influence of PT on curing of the coating film, attenuated total reflection Fourier transform infrared spectroscopy was used.

\section{MATERIALS AND METHODS}

\section{MATERIJALI I METODE}

\subsection{Particleboard as a substrate}

2.1. Iverica kao podloga

As a substrate, samples of a particleboard with dimensions of $(100 \times 100 \times 3) \mathrm{mm}^{3}$ were selected. Before future processing, the samples were conditioned in a chamber with a temperature of $20^{\circ} \mathrm{C}$ and relative humidity of $65 \%$ for three weeks. After conditioning, the substrate density of $857 \mathrm{~kg} / \mathrm{m}^{3}$ was determined gravimetrically.

\subsection{Plasma treatment of substrates surfaces and} formation of coating systems

2.2. Obrada površine podloge plazmom i formiranje sustava premaza

The surface of each individual sample was treated with FE-DBD non-thermal plasma in air at atmos- pheric pressure, as presented in previous publications (Žigon et al., 2019). For plasma ignition, an alternating high voltage (frequency $5 \mathrm{kHz}, 15 \mathrm{kV}$ peak voltage) was introduced in the insulated brass electrodes. The treated particleboard workpiece was moving with a moving rate of $2 \mathrm{~mm} / \mathrm{s}$ below the electrodes, and the air discharge occurred in the gaps between the dielectrics and the samples surface (Figure 1). The distance between the dielectrics was set to $5 \mathrm{~mm}$, while the distance between the dielectrics and the surface of the workpiece was about $1 \mathrm{~mm}$.

The samples were coated immediately after PT process, with a black shaded commercial acrylic waterborne coating (Belinka Interier, Belinka Belles, d.o.o., Ljubljana, Slovenia), with a solid content of $34.9 \%$, determined according to ISO 3251 (2008). The coating with a wet film thickness of $240 \mu \mathrm{m}$ (approximately $150 \mathrm{~g} / \mathrm{m}^{2}$ ) was manually applied with a quadruple coating applicator on the surface of control, untreated, PT samples. For reference measurements of coating hardness and ATR FT-IR spectroscopy, glass samples with applied coating were also prepared. Prior to further testing and analyses, the samples were stored in a conditioning chamber with relative humidity of $65 \%$ at $20^{\circ} \mathrm{C}$ for 21 days.

\subsection{Contact angle measurements}

2.3. Mjerenje kontaktnog kuta

Droplets of distilled water and coating were deposited on untreated and PT particleboard surfaces (5 samples per series) by Theta optical goniometer (Biolin Scientific Oy, Espoo, Finland), and CA measurements were made by Young-Laplace analysis using the software (OneAttension version 2.4 [r4931], Biolin Scientific, Espoo, Finland). Droplets with a volume of $5 \mu \mathrm{L}$ were applied on 4 different places per sample, while their shape was automatically recorded and analyzed within $60 \mathrm{~s}$ (1.9 frames per second) after deposition.

\subsection{Determination of hardness}

2.4. Određivanje tvrdoće

Hardness of the untreated and coated, and PT and coated samples ( 5 samples per series, 5 measurements per sample) was determined by the pendulum damped oscillations test method using König pendulum tester (Model 299/300, Erichsen GmbH \& Co. KG, Hemer, Germany; EN ISO 1522, 2007). The hardness value corresponded to the damping time of the pendulum oscillating on the sample surface from $6^{\circ}$ to $3^{\circ}$, with respect to normal axis, measured with an electronic counter.

Insulated electrode connected to high voltage source izolirana elektroda spojena na izvor visokog napona

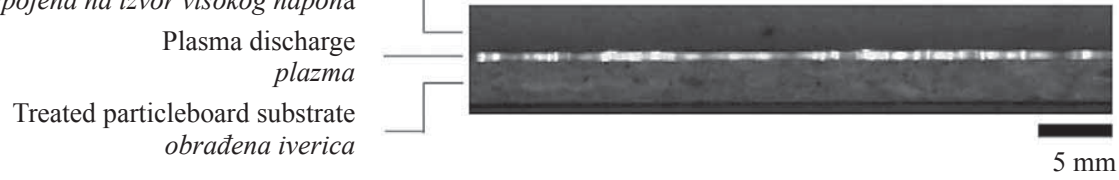

Figure 2 Treatment of particleboard substrate with air discharge plasma

Slika 2. Obrada iverice plazmom 


\subsection{Abrasion resistance tests}

\subsection{Ispitivanje otpornosti na abraziju}

The abrasion resistance tests were performed according to the Taber Abraser method (EN 438-2, 2016) on 10 samples per series. After weighing, the specimens were mounted into the rotary platform abrasion tester (Model 503, Erichsen GmbH \& Co. KG, Hemer, Germany) and abraded with rotating rubber wheels covered with sanding paper S-42 and loaded with $500 \mathrm{~g}$ each. The abrasion process was stopped after 10 , 25 , and after every further 25 revolutions up to final 200 revolutions. After each stop, the samples were weighted and scanned. A fresh sanding paper was used with every sample. A mass loss of the sample was determined according to the following equation:

$$
\Delta m=\frac{m_{0}-m_{1}}{m_{0}}[g] \times 100[\%]
$$

$\Delta m$ - samples mass loss due to abrasion (g, \%)

$m_{0}$ - samples mass, before abrasion $(\mathrm{g})$

$m_{1}$ - samples mass, after abrasion (g)

The scans of the samples, taken during the abrasion test, were analyzed by measuring the percentage of the abraded area with the Fiji software (ImageJ $1.46 \mathrm{~d}$, Bethesda, Maryland, USA) by grey value set to 80 (ranging from 0 - total white to 255 - total black) (Schindelin et al., 2012; Altgen et al., 2019).

\subsection{Scanning electron microscopy (SEM)} investigations

2.6. Istraživanje pretražnim elektronskim mikroskopom (SEM)

The cross sections of the untreated and PT samples in the region of abrasion were analyzed with SEM FEI Quanta 250 (FEI, Hillsboro, Oregon, USA). Before the start of observation, the surfaces were evened by microtome. Possible differences in the microstructure between untreated and PT substrates were analyzed with a large field (LFD) and circular backscattered (CBD) detector. The dry film thickness of the coating and its penetration depth were measured on 20 spots of the cross sections as well. The micrographs were taken at $100 \times$ and $500 \times$ magnification in a low vacuum $(50 \mathrm{~Pa})$, the electron source voltage of $10.0 \mathrm{kV}$, at a working distance of $10 \mathrm{~mm}$, and the spot size of 3.0. During the capture of the image, the time of the beam transition through the sample was $45 \mu \mathrm{s}$.

\subsection{Attenuated total reflection Fourier transform} infrared (ATR FT-IR) spectroscopy

2.7. Pojačana infracrvena spektroskopija uz prigušenu totalnu refleksiju (ATR FT-IR)

ATR FT-IR spectroscopic measurements of the dry coating film on glass, untreated and PT particleboard were performed using a Perkin Elmer Spectrum Two spectrometer (PerkinElmer Inc., Waltham, Massachusetts, USA), with a $\mathrm{LiTaO}_{3}$ detector in the absorbance mode. The spectra were measured on 5 different spots (16 scans per spot) of the coated samples, at a wavelength range from $600 \mathrm{~cm}^{-1}$ to $4000 \mathrm{~cm}^{-1}$ and at a resolution of $0.5 \mathrm{~cm}^{-1}$. For later comparison, ATR FTIR spectra were also recorded on coated glass samples.

\section{RESULTS AND DISCUSSION}

\section{REZULTATI I RASPRAVA}

\subsection{Contact angles of liquids on untreated and PT} substrates

3.1. Kontaktni kutovi tekućina na neobrađenim podlogama i podlogama obrađenim plazmom

Average values of apparent CA of water and coating droplets during the first $60 \mathrm{~s}$ after application are depicted in Figure 2. On the right side, the photos of the droplets immediately after deposition are shown. The surface of the particleboard treated in this study turned out to be less prone to interact with water, but the values are in agreement with findings in the literature (Baharoğlu et al., 2012; Sandak et al., 2015), since the measured CA of water droplets were above $100^{\circ}$. This might be related to relatively high density of the substrate, applied higher temperature during pressing in the production of boards and consequently physical-chemical modifications of the surface, presence of the adhesive and other possible water repellent constituents on its surface. Treatment of the surface with plasma lowered the CA of water by about $15^{\circ}$, making the surface more hydrophilic. However, CA of applied coating droplets was lower in comparison to water CA. Here, the influence of PT to make the surface more susceptible to coating was less pronounced, but obvious (about $5^{\circ}$ lower CA). Wolkenhauer and co-authors (2008) found an enhanced absorbency of a waterborne formulation (i.e. polyvinyl acetate adhesive) into particleboard surfaces treated with atmospheric DBD plasma. According to their findings, the reason for that could be the enhanced hydrophilicity of the surface treated with the formulation containing waterborne polymer.

3.2 Surface hardness
3.2. Tvrdoća površine

The pendulum hardness test is based on the principle that the harder the measured surface, the greater the oscillation time of the pendulum. The amplitude of the pendulum oscillation decreases gradually because of the damping during the pendulum hardness test. The pendulum hardness of the coating is greatly related to its dry film thickness (Ma et al., 2013). There were no significant differences in the average thickness of the dry coating film (about $45 \mu \mathrm{m}$ ), measured on untreated and PT sample with SEM at different spots. From the results shown in Figure 3, it can be seen that a coating film applied on a glass plate (thickness film about $65 \mu \mathrm{m}$ ) had a very low oscillation time, meaning high damping of the pendulum due to the elastic deformations of the film. The coatings applied on untreated substrates exhibited slightly lower average oscillation time (about $1 \mathrm{~s}$ ) than a coating applied on PT substrate. However, the increase in film hardness of $4 \%$ for the PT substrate as compared to the one on untreated substrate is not significant due to the relatively low statistics. It is thus not possible to deduce any influence on the bulk hardness by PT prior to coating application. Therefore, further investigations are required to determine possible alternations of the curing process of this coating due to PT. 


\begin{tabular}{|c|c|}
\hline$\square$ Untreated-Water / neobrađeno - voda & $\diamond$ Treated-Water / obrađeno - voda \\
\hline $\begin{array}{l}\text { Untreated-Coating / neobrađeno - } \\
\text { premazni materijal }\end{array}$ & $\begin{array}{l}\Delta \text { Treated-Coating / obrađeno } \\
\quad \text { - premazni materijal }\end{array}$ \\
\hline
\end{tabular}

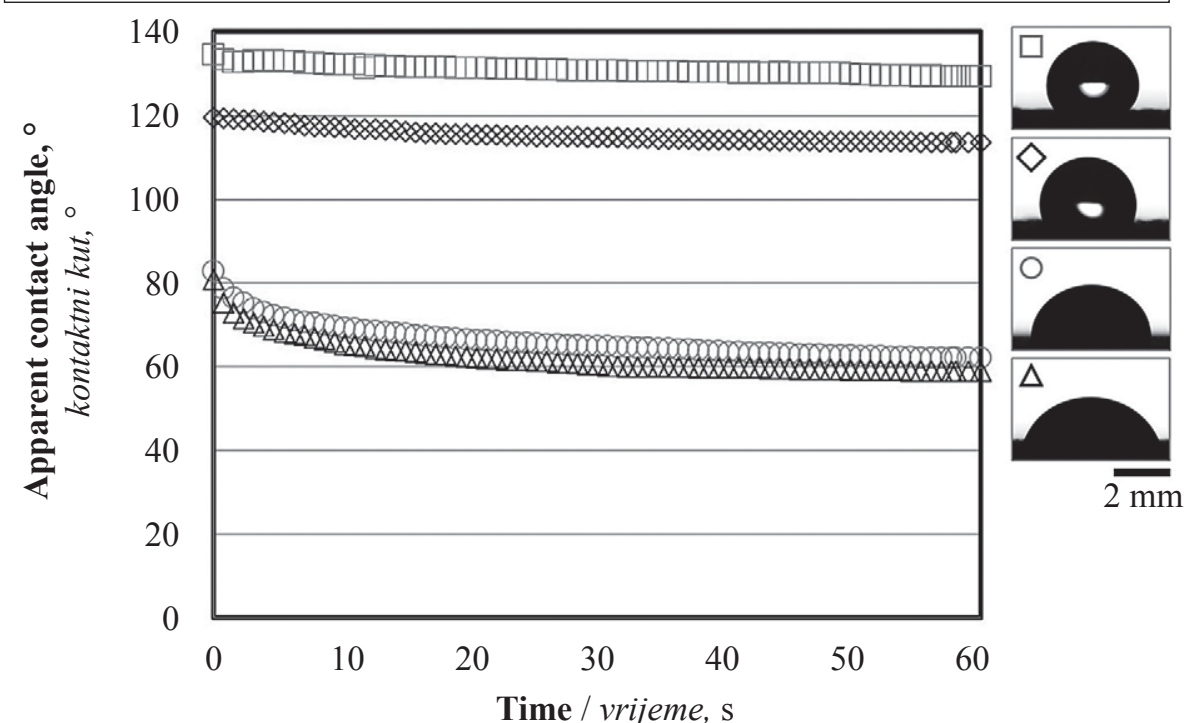

Figure 2 Apparent contact angles of water and coating droplets applied on untreated and PT substrates surfaces. On the right side, photos of droplets immediately after deposition are shown

Slika 2. Kontaktni kut vode i premaznog materijala nanesenoga na neobrađenu i plazmom obrađenu podlogu (na desnoj su strani fotografije kapi neposredno nakon nanošenja na podlogu)

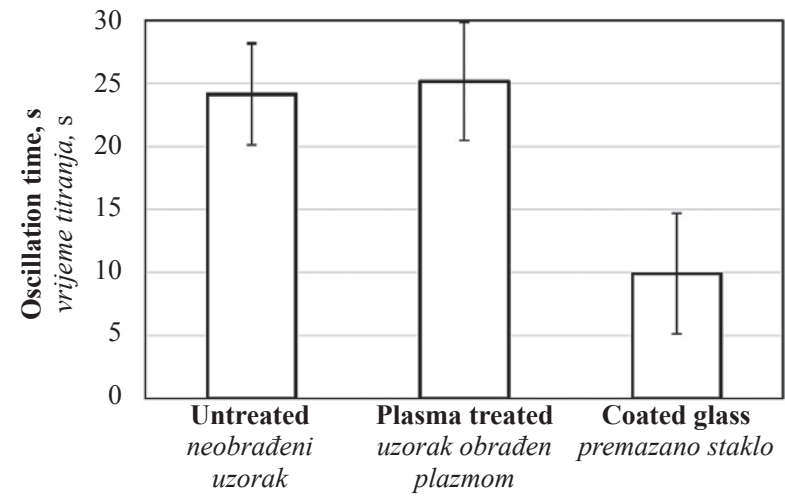

Figure 3 Pendulum oscillation times of waterborne acrylic coating films applied on untreated and PT particleboard substrate, and on glass

Slika 3. Vrijeme titranja njihala filma vodenoga poliakrilatnog premaza nanesenoga na neobrađenu i plazmom obrađenu površinu uzorka te na staklo

\subsection{Resistance to abrasion}

3.3. Otpornost na abraziju

Figures of representative samples, taken during the abrasion test after a certain number of revolutions are shown in Table 1. Visual differences between untreated samples and PT samples are summarized in Figure 4, showing detected pixels by grey value set to 80 . The differences in the amount of abraded coating were shown already after the first 25 revolutions. After 100 revolutions, the differences reached the maximum (about $6 \%$ ), and at the final amount of revolutions, the surface system with untreated substrate was completely abraded, while at PT ones, some coating still remained.

The mass losses during the abrasion test of the samples are in agreement with other results shown in this paragraph (Figure 5). The absolute mass losses with respect to the masses of the whole samples are

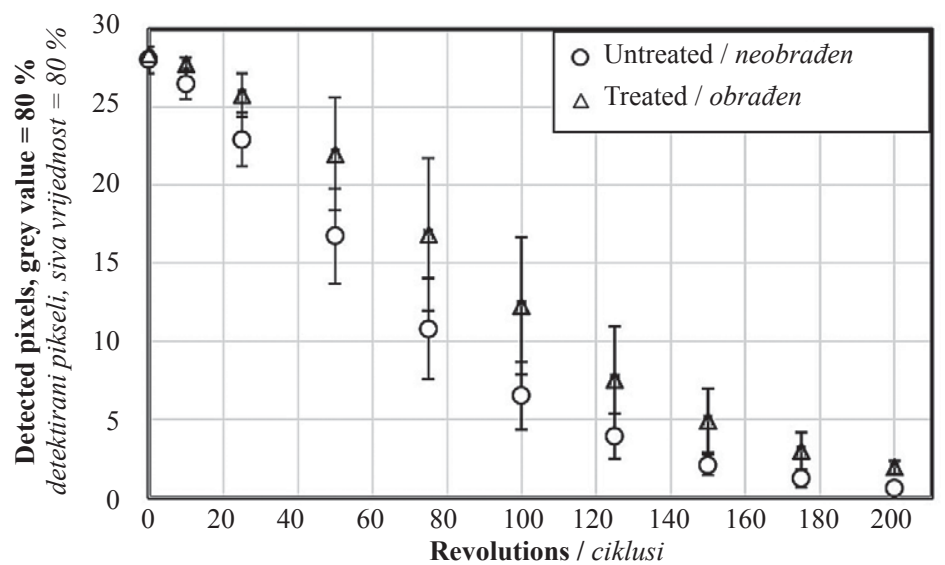

Figure 4 Detected pixels as percentage of remained coating on abraded area during abrasion resistance test on untreated or PT substrates

Slika 4. Detektirani pikseli kao postotak preostalog premaza na istrošenom području tijekom ispitivanja otpornosti na abraziju na neobrađenim i plazmom obrađenim podlogama 
Table 1 Appearance of representative samples after a specific number of revolutions in abrasion resistance test. Left side of images is shown as processed with Fiji software for grey value analysis

Tablica 1. Izgled reprezentativnih uzoraka nakon određenog broja ciklusa ispitivanja otpornosti na abraziju. Lijeva strana fotografija obrađena je Fiji softverom za analizu sive vrijednosti.

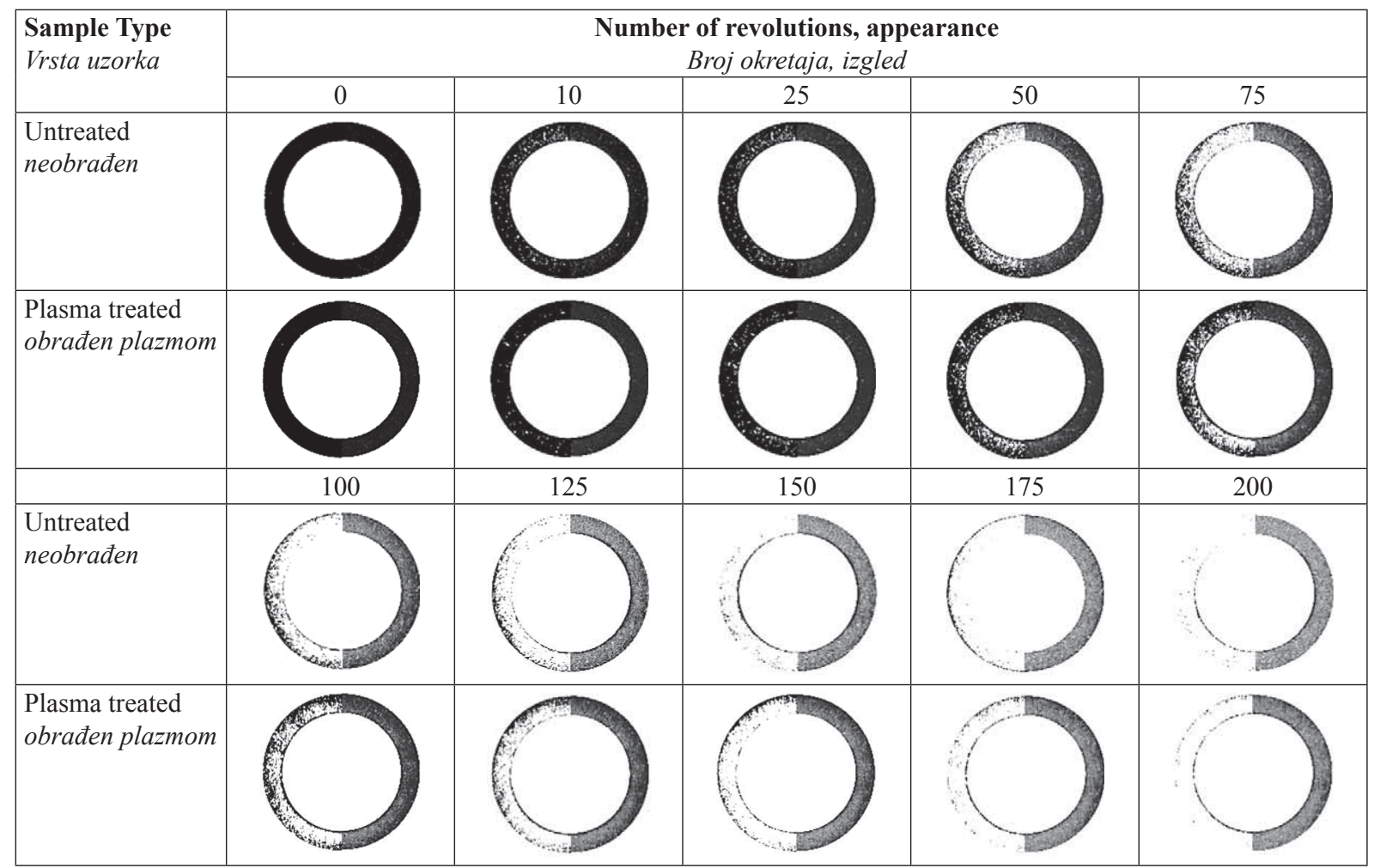

lower than $1 \%$, but expected, since only a part of the coating was removed, and at the end of the tests a part of the substrate was removed as well. The results showed that on the samples, treated with plasma prior to coating process, less material was removed. From the results of visual estimation and detected mass losses, it can be concluded that increased abrasion resistance of PT samples is related to a greater hardness of the coating film applied on such a substrate.

\subsection{SEM micrographs}

\subsection{SEM mikrografije}

Figure 6 shows micrographs of samples cross sections detected with LFD and CBD detectors. The micrographs were captured in the region comprising non-abraded (central) part of the samples surface and part with abraded surface.

On the abraded area of an untreated sample (Figure 6a) no coating is present, whereas at the PT sample after 200 revolutions some coating still remained on the surface (Figure 6b). The reason for that could be a greater hardness of the coating film and/or deeper penetration of the coating by treated substrate. However, due to compressed structure of the cells, it was hard to estimate the coating penetration depth and make constructive conclusions about the latter between untreated and PT samples.

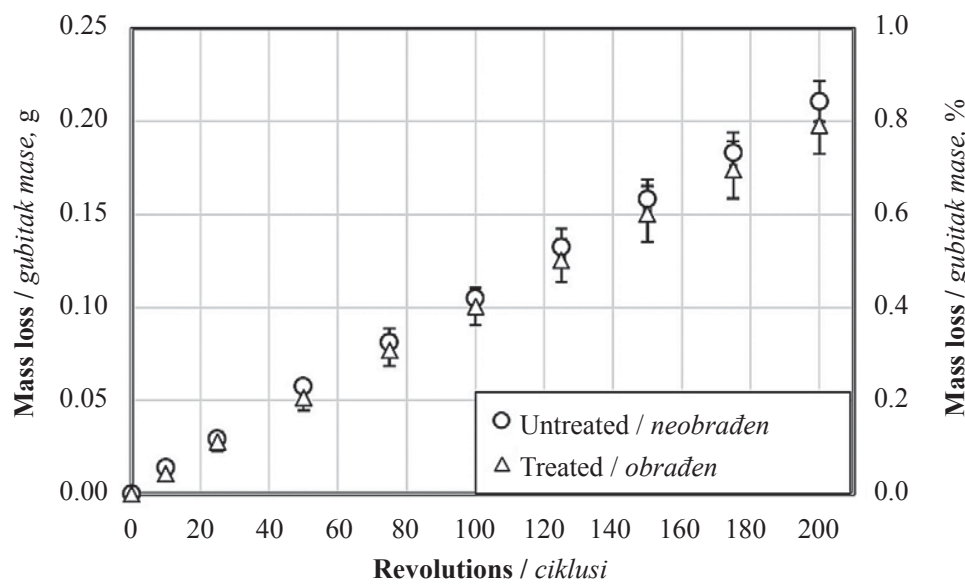

Figure 5 Absolute mass loss of surface systems during abrasion resistance test with respect to mass of the whole sample, previously untreated or treated with plasma

Slika 5. Apsolutni gubitak mase površinskih sustava, prethodno neobrađenih i obrađenih plazmom, tijekom ispitivanja otpornosti na abraziju u odnosu prema masi cijelog uzorka 


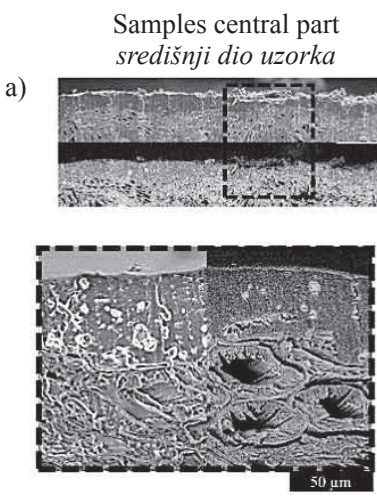
Abraded area
istrošeno područje
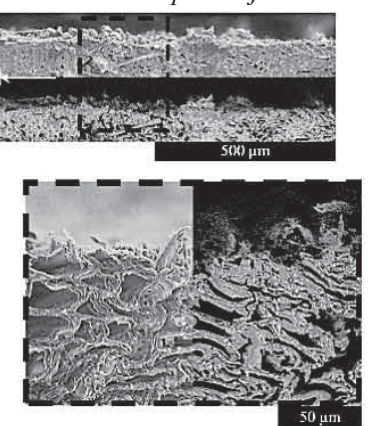

b)

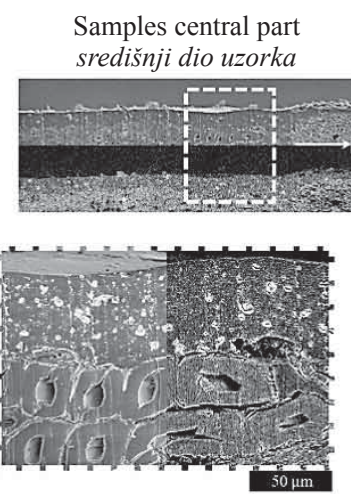

Abraded area istrošeno područje 1. 1 1

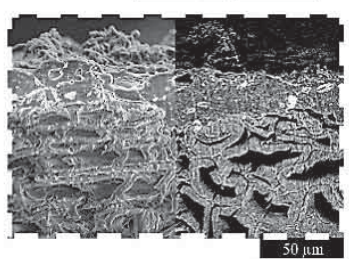

Figure 6 SEM micrographs of samples after abrasion resistance test: a) untreated substrate, b) substrate treated with plasma Slika 6. SEM mikrografije uzoraka nakon ispitivanja otpornosti na abraziju: a) neobrađena podloga, b) podloga obrađena plazmom

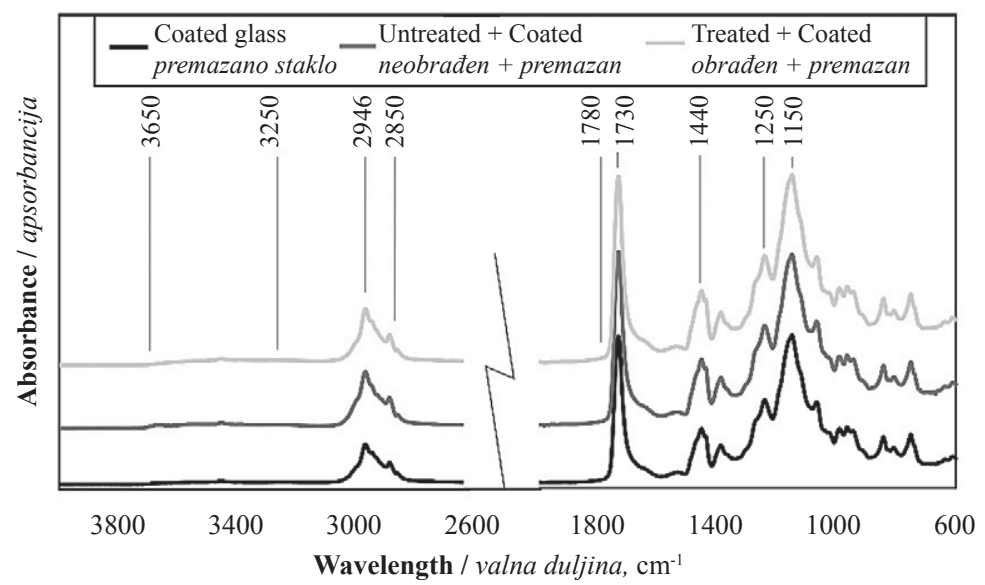

Figure 7 ATR-FTIR spectra of waterborne acrylic coating films, applied on glass, and untreated and PT particleboard substrate Slika 7. ATR-FTIR spektar filma poliakrilatnog premaza nanesenoga na staklo i na neobrađenu i plazmom obrađenu ivericu

\subsection{ATR FT-IR spectra}

\subsection{ATR FT-IR spektri}

Infrared spectroscopy is a sensitive and reliable technique, which permits to quantify the chemical changes of the chemical structure of polymer materials. Figure 7 shows the infrared spectra of waterborne acrylic coating films, applied on glass, and untreated and PT particleboard substrate. Some IR characteristic bands of functional groups, such as $\mathrm{O}-\mathrm{H}$ (3650 and $3250 \mathrm{~cm}^{-1}$ ), alkane C-H (2946 and $\left.2850 \mathrm{~cm}^{-1}\right)$, carboxylic acid CO $\left(1780,1730\right.$ and $\left.1440 \mathrm{~cm}^{-1}\right)$, ester $\mathrm{C}-\mathrm{O}-$ (1730 and $\left.1250 \mathrm{~cm}^{-1}\right)$ and aliphatic ether $\left(1150 \mathrm{~cm}^{-1}\right)$, are marked (Scalarone et al., 2007; Nguyen et al., 2016). By comparing the main peaks of all three spectra, it can be seen that no changes between them were detected. Therefore, the higher hardness of the coating film due to prior PT of the substrate could not be explained by this technique.

\section{CONCLUSIONS}

\section{ZAKLJUČAK}

Particleboards were successfully treated using FE-DBD plasma in air at atmospheric pressure, yielding an increased abrasion resistance of waterborne coating according to both visual estimation and mass losses after a specific number of revolutions. The reason for such behavior could be related to greater hardness (oscillation time $1 \mathrm{~s}$ or $4 \%$ longer) of the surface system with PT substrates and enhanced wettability of the substrate with both water (CA lower for about $15^{\circ}$ ) and coating (CA lower for about $5^{\circ}$ ). Similar to visual estimation of abraded coating in the abrasion test, the investigation of the cross section structures on microscopic level showed the differences in the amounts of coating remained on the abraded areas. Investigations with ATR-FTIR revealed that PT did not have effects on chemical composition of the coating film, which could be the reason for higher hardness detected on these samples.

For a better understanding of the properties of such surface systems, further studies should be performed to investigate the influence of PT, prior to coating application, on their resistance to other impacts.

\section{Acknowledgements - Zahvala}

The authors acknowledge the financial support of the Slovenian Research Agency (research program funding No. P4-0015, "Wood and Lignocellulose Composites").

This project has received funding from the European Union's Horizon 2020 research and innovation program under grant agreement No. 745936 . 


\section{REFERENCES}

\section{LITERATURA}

1. Altgen, D.; Bellmann, M.; Wascher, R.; Viöl, W.; Mai, C., 2015: Enhancing mechanical properties of particleboards using plasma treated wood particles. European Journal of Wood and Wood Products, 73: 219-223. https://doi.org/10.1007/s00107-015-0879-z.

2. Altgen, D.; Grigsby, W.; Altgen, M.; Rautkari, L.; Mai, C., 2019: Analyzing the UF resin distribution in particleboards by confocal laser microscopy. Composites, Part A, 125: 105529 .

https://doi.org/10.1016/j.compositesa.2019.105529.

3. Aytin, A.; Korkut, S.; As, N.; Ünsal, Ö.; Gündüz, G., 2015: Effect of Heat Treatment of Wild Cherry Wood on Abrasion Resistance and Withdrawal Capacity of Screws. Drvna industrija, 66 (4): 297-303.

https://doi.org/10.5552/drind.2015.1440.

4. Baharoğlu, M.; Nemli, G.; Sarı, B.; Bardak, S.; Ayrılmış, N., 2012: The influence of moisture content of raw material on the physical and mechanical properties, surface roughness, wettability, and formaldehyde emission of particleboard composite. Composites, Part B, 43 (5): $2448-2451$ https://doi.org/10.1016/j.compositesb.2011.10.020.

5. Bardak, S.; Sarı, B.; Nemli, G.; Kırc1, H.; Baharoğlu, M., 2011: The effect of décor paper properties and adhesive type on some properties of particleboard. International Journal of Adhesion and Adhesives, 31: 412-415. https://doi.org/10.1016/j.ijadhadh.2011.02.008.

6. Bauer, F.; Flyunt, R.; Czihal, K.; Buchmeiser, R. M.; Langguth, H.; Mehnert, R., 2006: Nano/micro particle hybrid composites for scratch and abrasion resistant polyacrylate coatings. Macromolecular Materials and Engineering, 291: 493-498. https://doi.org/10.1002/mame.200600034.

7. Brischke, C.; Ziegeler, N.; Bollmus, S., 2019: Abrasion resistance of thermally and chemically modified timber. Drvna idustrija, 70 (1): 71-76.

https://doi.org/10.5552/drvind.2019.1813.

8. Cristea, M. V.; Riedl, B.; Blanchet, P., 2011: Effect of addition of nanosized UV absorbers on the physico-mechanical and thermal properties of an exterior waterborne stain for wood. Progress in Organic Coatings, 72: 755762. https://doi.org/10.1016/j.porgcoat.2011.08.007.

9. De Cademartori, P. H. G.; De Carvalho, A. R.; Marangoni, P. R. D.; Berton, M. A. C.; Blanchet, P.; De Muniz, G. I. B.; Magalhães, W. L. E., 2016: Adhesion performance and film formation of acrylic emulsion coating on medium density fibreboard treated with Ar plasma. International Journal of Adhesion and Adhesives, 70: 322328. https://doi.org/10.1016/j.ijadhadh.2016.08.002.

10. Gurleyen, L.; Ayata, U.; Esteves, B.; Cakicier, N., 2017: Effects of heat treatment on the adhesion Strength, pendulum hardness, surface roughness, color and glossiness of scots pine laminated parquet with two different types of UV varnish application. Maderas. Ciencia y tecnología 19 (2): 213-224. https://doi.org/10.4067/s0718-221x2017005000019.

11. Haase, G. J.; Leung, H. L.; Evans, D. P., 2019: Plasma pre-treatments to improve the weather resistance of polyurethane coating on black spruce wood. Coatings, 9 (1). https://doi.org/10.3390/coatings9010008.

12. Istek, A.; Aydemir, D.; Aksu, S., 2010: The effect of décor paper and resin type on the physical, mechanical, and surface quality properties of particleboards coated with impregnated décor papers. BioResources, 5 (2): 10741083.
13. Keskin, H.; Tekin, A., 2011: Abrasion resistances of cellulosic, synthetic, polyurethane, waterborne and acidhardening varnishes used woods. Construction and Building Materials, 25: 638-643.

https://doi.org/10.1016/j.conbuildmat.2010.07.028.

14. Ko, C.-L.; Kuo, Y.-L.; Lee W.-J.; Sheng, H.-J.; Guo, J.Y., 2018: The enhanced abrasion resistance of an antifingerprint coating on chrome-plated brass substrate by integrating sputtering and atmospheric pressure plasma jet technologies. Applied Surface Science, 448: 88-94. https://doi.org/10.1016/j.apsusc.2018.04.075.

15. Liston, E. M.; Martinu, L.; Wertheimer, M. R., 1993: Plasma surface modification of polymers for improved adhesion: a critical review. Journal of Adhesion Science and Technology, 7 (10): 1091-1127.

16. Ma, X.; Qiao, Z.; Huang, Z.; Jing, X., 2013: The dependence of pendulum hardness on the thickness of acrylic coating. Journal of Coatings Technology and Research, 10 (3) 433-439.

https://doi.org/10.1007/s11998-013-9477-3.

17. Moghadamzadeh, H.; Rahimi, H.; Asadollahzadeh, M.; Hemmati, R. A., 2011: Surface treatment of wood polymer composites for adhesive bonding. International Journal of Adhesion and Adhesives, 31: 816-821.

18. Nemli, G.; Örs, Y.; Kalaycığlu, H., 2005: The choosing of suitable decorative surface coating material types for interior end use applications of particleboard. Construction and Building Materials, 19: 307-312. https://doi. org/10.1016/j.conbuildmat.2004.07.015.

19. Nemli, G.; Hiziroglu, S., 2009: Effect of press parameters on scratch and abrasion resistance of overlaid particleboard panels. Journal of Composite Materials, 43 (13): 1413-1420. https://doi.org/10.1177/0021998308103416.

20. Nguyen, T. V.; Nguyen-Tri, P.; Nguyen, T. D.; El Aidani, R.; Trinh, V. T.; Decker, C., 2016: Accelerated degradation of water borne acrylic nanocomposites used in outdoor protective coatings. Polymer Degradation and Stability, 128: 65-76.

https://doi.org/10.1016/j.polymdegradstab.2016.03.002.

21. Perisse, F.; Menecier, S.; Duffour, E.; Vacher, D.; Monier, G.; Destrebecq, J.-F.; Czarniak, P.; Górski, J.; Wilkowski, J., 2017: MDF treatment with a Dielectric Barrier Discharge (DBD) torch. International Journal of Adhesion and Adhesives, 79: 18-22. https://doi.org/10.1016/j.ijadhadh.2017.09.006.

22. Reinprecht, L.; Tiňo, R.; Šomšák, M., 2018: Adhesion of coatings to plasma modified wood at accelerated weathering. In: European Conference on Wood Modification 2018 (ECWM9), Creemers, J.; Houben, T.; Tjeerdsma, B.; Militz, H.; Junge, B.; Gootjes, J. Arnhem (eds.), The Netherlands (On-line Proceedings), 205-209.

23. Rolleri, A.; Roffael, E., 2010: Influence of the surface roughness of particleboards and their performance towards coating. Maderas ciencia y tecnologia, 12 (2): 143148.https://doi.org/10.4067/s0718-221x2010000200009.

24. Rossi, S.; Deflorian, F.; Fontanari, L.; Cambruzzi, A.; Bonora, P. L., 2005: Electrochemical measurements to evaluate the damage due to abrasion on organic protective system. Progress in Organic Coatings, 52: 288-297. https://doi.org/10.1016/j.porgcoat.2004.09.005.

25. Rossi, S.; Deflorian, F.; Scrinzi, E., 2009: Comparison of different abrasion mechanisms on aesthetic properties of organic coatings. Wear, 267: 1574-1580. https://doi.org/10.1016/j.wear.2009.06.021.

26. Sandak, J.; Sandak, A.; Hiziroglu, S.; Bosak, S., 2015: Surface characterization of particleboard panels manu- 
factured from eastern redcedar using a multi-sensor approach. International Panel Products Symposium, At Llandudno, North Wales, UK: 27-37.

27. Scalarone, D.; Lazzari, M.; Castelvetro, V.; Chiantore, O., 2007: Surface monitoring of surfactant phase separation and stability in waterborne acrylic coatings. Chemistry of Materials, 19: 6107-6113. https://doi.org/10.1021/cm0714077.

28. Schindelin, J.; Arganda-Carreras, I.; Frise, E.; Kaynig, V.; Longair, M.; Pietzsch, T.; Preibisch, S.; Rueden, C.; Saalfeld, S.; Schmid, B.; Tinevez, J.-Y.; White, J. D.; Hartenstein, V.; Eliceiri, K.; Tomancak, P.; Cardona, A., 2012: Fiji - an Open Source platform for biological image analysis. Nat. Methods 9(7): 676-682.

29. Scrinzi, E.; Rossi, S.; Deflorian, F.; Zanella, C., 2011: Evaluation of aesthetic durability of waterborne polyurethane coatings applied on wood for interior applications. Progress in Organic Coatings, 72: 81-87. https://doi.org/10.1016/j.porgcoat.2011.03.013.

30. Sell, J.; Feist, W. C., 1986: Role of density in the erosion of wood during weathering. For. Prod. J., 36 (3): 57-60.

31. Sönmez, A.; Budakçı, M.; Pelit, H., 2011: The effect of the moisture content of wood on the layer performance of water-borne varnishes. BioResources, 6 (3), 3166-3178.

32. Veigel, S.; Grüll, G.; Pinkl, S.; Obersriebnig, M.; Müller, U.; Gindl-Altmutter, W., 2014: Improving the mechanical resistance of waterborne wood coatings by adding cellulose nanofibers. Reactive and Functional Polymers, 85: 214-220.

https://doi.org/10.1016/j.reactfunctpolym.2014.07.020.

33. Welzbacher, C.; Brischke, C.; Rapp, A.; Koch, S.; Hofer, S., 2009: Performance of thermally modified timber (TMT) in outdoor application - durability, abrasion and optical appearance. Drvna industrija, 60 (2): 75-82.

34. Wolf, R.; Sparavigna, A. C., 2010: Role of plasma surface treatments on wetting and adhesion. Engineering, 2: 397-402. https://doi.org/10.4236/eng.2010.26052.
35. Wolkenhauer, A.; Militz, H.; Viöl, W., 2008: Increased PVA-glue adhesion on particle board and fibre board by plasma treatment. Holz als Roh- und Werkstoff, 66: 143145. https://doi.org/10.1007/s00107-007-0217-1.

36. Wolkenhauer, A.; Avramidis, G.; Hauswald, E.; Loose, S.; Viöl, W.; Militz, H., 2009: Investigations on the drying behaviour of adhesives on plasma-treated wood materials. Wood Research, 54 (1): 59-66.

37. Žigon, J.; Petrič, M.; Dahle, S., 2018: Dielectric barrier discharge (DBD) plasma pretreatment of lignocellulosic materials in air at atmospheric pressure for their improved wettability: a literature review. Holzforschung, 72 (11): 979-991. https://doi.org/10.1515/hf-2017-0207.

38. Žigon, J.; Petrič, M.; Dahle, S., 2019: Artificially aged spruce and beech wood surfaces reactivated using FEDBD atmospheric plasma. Holzforschung, 73 (12): 1069-1081. https://doi.org/10.1515/hf-2019-0005.

39. ***EN 438-2, 2016: High-pressure decorative laminates (HPL) - Sheets based on thermosetting resins (usually called laminates), Part 2: Determination of properties.

40. ***EN ISO 1522, 2007: Paints and varnishes - Pendulum damping test.

41. ***ISO 3251, 2008: Paints, varnishes and plastics - Determination of non-volatile-matter content.

\section{Corresponding address:}

\section{JURE ŽIGON}

University of Ljubljana

Biotechnical Faculty

Department of Wood Science and Technology Jamnikarjeva 101, 1000 Ljubljana, SLOVENIA e-mail: jure.zigon@bf.uni-lj.si 